\title{
Kenaikan Tarif BPJS Kesehatan, Obat Defisit yang Tak Bisa Dihindari
}

\author{
Patrianef Darwis ${ }^{1}$ \\ ${ }^{1}$ Divisi Bedah Vaskular dan Endovaskular Departemen Ilmu Bedah Fakultas Kedokteran Universitas \\ Indonesia/ Rumah Sakit Cipto Mangunkusumo
}

Sejawat sekalian, memasuki tahun 2020 sangat banyak kejadian yang terjadi di dunia kesehatan. Masalah kenaikan tarif BPJS Kesehatan yang masih banyak dtentang oleh banyak pihak tentu saja mempengaruhi kerja para spesialis bedah secara keseluruhan. Pengaruh ini terjadi secara langsung karena sebagian besar pembiayaan pasien saat ini menggunakan dana Jaminan Kesehatan Nasional yang diselenggarakan oleh BPJS Kesehatan.

Berdasarkan pasal 34 Perpres nomor 75 tahun 2019 maka akan terjadi kenaikan iuran BPJS Kesehatan pada 1 januari 2020. Kenaikan itu secara rinci adalah sebagai berikut:

- Kelas III dari Rp 25.500 per bulan menjadi Rp 42.000
- Kelas II dari Rp 51.000 menjadi Rp 110.000

- Kelas I dari Rp 80.000 menjadi Rp 160.000

Kenaikan tersebut juga berlaku bagi Penerima Bantuan Iuran (PBI) baik dari APBN maupun PBI yang berasal dari APBD. Khusus untuk kenaikan iuran PBI yang dibayarkan pemerintah ini, akan terjadi kenaikan daari Rp 23.000 per bulan menjadi Rp 42.000 .

Tentu saja kenaikan tersebut berpengaruh positif bagi seluruh rumah sakit yang banyak mengandalkan pasien BPJS Kesehatan, terutama rumah sakit di daerah.

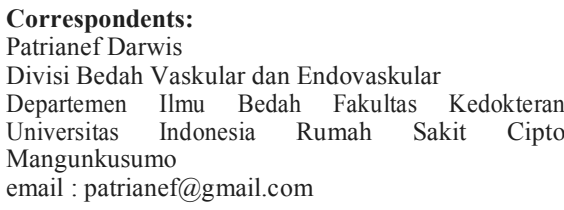


Pelayanan kesehatan selama ini terganggu karena aliran dana dari pembiayaan ke rumah sakit sering terlambat beberapa bulan. Hal itu tidak terlepas akibat defisit yang dialami oleh BPJS kesehatan yang semakin meningkat dari tahun ke tahun. Secara langsung aliran yang terhambat dan terlambat tersebut juga mempengaruhi para dokter yang bekerja di RS tersebut, termasuk dokter spesialis bedah.

Defisit yang dialami oleh BPJS Kesehatan sudah berlangsung sejak than 2014. Pada tahun 2018 defisit yang dialami oleh BPJS Kesehatan sebanyak Rp 19,4 T dan ditalangi oleh pemernah sebanyak $\mathrm{Rp}$ 10,3 $\mathrm{T}$ dan defisit dibawa ke tahun 2019 sebanyak Rp 9,1 T. Pada tahun 2019 defisit semakin melebar mencapai Rp 32,84 T ini termasuk beban defisit Rp 9,1 T yang dibawa ke tahun 2019. Pada tahun 2019 ini pemerintah menalangi defisit sebanyak $\mathrm{Rp}$ 14 Tsehingga ada beban defisit sebanyak Rp 18,84 T yang dibawa ke tahun 2020 .

Tanpa adanya kenaikan iuran maka beban defisit akan semakin melebar tahun 2020. Diperkirakan defisit tahun 2020 mencapai Rp $31 \mathrm{~T}$ dan ditambah dengan beban defisit tahun 2019 yang dbawa ke tahun 2020 sebanyak Rp 18 T maka defsit akan semakin melebar. Hal ini akan semakin memperburuk pelayanan di rumah sakit yang sudah tertekan oleh penundaan pembayaran pelayanan pasien beberapa bulan oleh BPJS Kesehatan.

Sejawat sekalian, kenaikan iuran BPJS kesehatan sepertinya memang keniscayaan yang tak dapat ditunda lagi dan sangat mendesak, hall ini akibat defisit yang dialami oeh BPJS Kesehatan yang sudah berlangsung 5 tahun terus menerus dan semakin membesar tetapi persoalannya adalah seberapa besar kenaikan tersebut dan apakah kenaikan tersebut masih mampu ditanggung oleh masyarakat. Kita paham bahwa orang miskin pembiayaannya ditanggung oleh pemerintah baik melalui dana APBN maupun dana APBD. Persoalannya adalah apakah semua orang miskin sudah terdata baik dan masuk dalam daftar penerima bantuan PBI.

Sebagai seorang spesialis bedah tentu saja kita tidak bisa berlepas diri dari gonjang ganjing di dunia kesehatan tersebut, apalagi hal ini menyangkut pembiayaan pasien kita. Bagaimanapun tindakan pada pasien yang dilakukan para spesialis bedah memerlukan pembiayaan yang tidak sedikit.

Harapan kita bersama tahun 2020 didepan akan lebih baik dari tahun lalu.

(ISSN:0216-0951 J Bedah Indonesia. 2019; 47:2) 